\title{
AN IMPROVED TECHNIQUE FOR THE MICROSCOPIC DIAGNOSIS OF LIVER-FLUKE INFECTION IN CATTLE
}

\section{JOSÉ D. RIVERA ANAYA AND JOSÉ MARTÍNEZ DE JESÚS' ${ }^{1}$}

The diagnosis of internal parasitism in livestock is of unquestionable importance both in veterinary research and routine work. The finding and identification of parasitic ova in feces in microscopic examination helps to establish a definite diagnosis in the case under consideration.

The common liver fluke (Fasciola hepatica) is an important enzootic parasite of cattle in Puerto Rico. Identification of the fluke ovum is relatively easy, as it has a characteristic shape and size and a single polar operculum. Because fluke ova are not suitable for flotation in solutions of high specific gravity in which they collapse and become distorted, and because clumps of fecal particles mask the ova and make their observation and identification difficult, different techniques were studied trying to obviate these problems.

The method for fluke-ova identification as used by Oliver $(1)^{2}$ requires very little equipment and is simple in procedure. However, in pouring off the supernatant fluid, the sediment in the conical sedimentation glass is disturbed and there is the risk of throwing away part or all of the fluke eggs present, thus making the diagnosis of fascioliasis very difficult.

Swanson and Hopper (2) have worked out a reliable technique for the quantitative examination of fasciola-eggs. However, it takes time, and several pieces of laboratory equipment are necessary.

To obviate some of these handicaps an improvement to this method (Swanson and Hopper) has been devised, in which several steps are omitted and the rate of sedimentation is increased.

The procedure is as follows:

1 -Collect a gross sample of $500 \mathrm{gm}$. of feces from the rectum.

2 -Place the sample in a 1,000-ml. beaker and mix thoroughly.

3-Take a 5-gm. sample (by taking small amounts from various parts of the gross sample); put it into a 250-ml. Erlenmeyer flask. Add $100 \mathrm{ml}$. of tap water and shake until a uniform suspension is obtained.

4-Wash the sample through a series of wire-screens (20-, 40-, and 60mesh) into a 1,000-ml. beaker, and transfer the suspension to a graduated glass cylinder, $1,000 \mathrm{ml}$. volume.

5 -Add $1 \mathrm{ml}$. of a 1-percent solution of aluminum sulfate to the fecal suspension and stir thoroughly. Let the mixture settle for 10 to $15 \mathrm{~min}$ -

${ }^{1}$ Associate Veterinarian and Research Assistant in Bacteriology, respectively, Agricultural Experiment Station, University of Puerto Rico, Rio Piedras, P.R.

${ }^{2}$ Numerals in parentheses refer to Literature Cited p. 99. 
utes. Siphon off the supernatant fluid to about three-fourths of an inch from the bottom by using a bent glass tube without disturbing the ova-containing sediment. One end of a glass tube-of a one-eighth-inch bore and about 12 inches in length is bent over a burner flame in a three-fourths inch $\mathbf{U}$ shape. To siphon the supernatant fluid off, connect the long straight end of the glass tube to a vacuum filter pump with a piece of rubber tubing.

6 -Add $1 \mathrm{ml}$. of standard tincture of iodine to the sediment; agitate to mix thoroughly, and let stand for 2 minutes. The tincture of iodine stains the fluke egg a deep brown color, making its identification easy.

7 -Pour the sediment into a 15-cc. centrifuge tube; centrifuge for 2 minutes at about 2,000 r.p.m.

8-Pour off all the supernatant fluid except $1 \mathrm{ml}$. This is left in so as to mix with the sediment and make it watery. Besides, the risk of pouring off fluke eggs is avoided by leaving this $1 \mathrm{ml}$. of fluid on top of the sediment.

9 -Mix the sediment well with a wooden applicator and transfer some onto a clean glass slide by using the applicator.

10 - Put a cover glass over the specimen and examine under the low and high powers of a microscope.

The advantages of this procedure in the diagnosis of liver-fluke infestation through a fecal examination and microscopical identification of the ova, as compared to the method of Swanson and Hopper (2) are:

1 - Several steps and the use of some pieces of laboratory equipment are eliminated.

2 -The time required for the examination is greatly reduced, as the sedimentation takes only 10 to 15 minutes after adding $1 \mathrm{ml}$. of a 1 -percent solution of aluminum sulfate.

3-The addition of $1 \mathrm{ml}$. of a 1-percent solution of aluminum sulfate, besides greatly shortening the time needed for sedimentation, does not exert any deleterious effect upon the shape of the fluke egg, hence does not interfere with the identification of liver-fluke ova.

4-The use of standard 7-percent tincture of iodine eliminates the preparation of special 15-percent tincture.

\section{LITERATURE CITED}

1. J. Oliver González-personal communication.

2. Leonard E. Swanson and Howard H. Hopper-Diagnosis of Liver Fluke Infection in Cattle. Journal of the A.V.M.A., vol. CXVII No. 881, p. 127, August 1950 . 